Informed Learning: $A$

Catalyst for Change in

Theological Libraries?

by Christine Bruce

\title{
Informed Learning: a catalyst for change in theological libraries?
}

Christine Bruce, Faculty of Science and Technology, QUT 

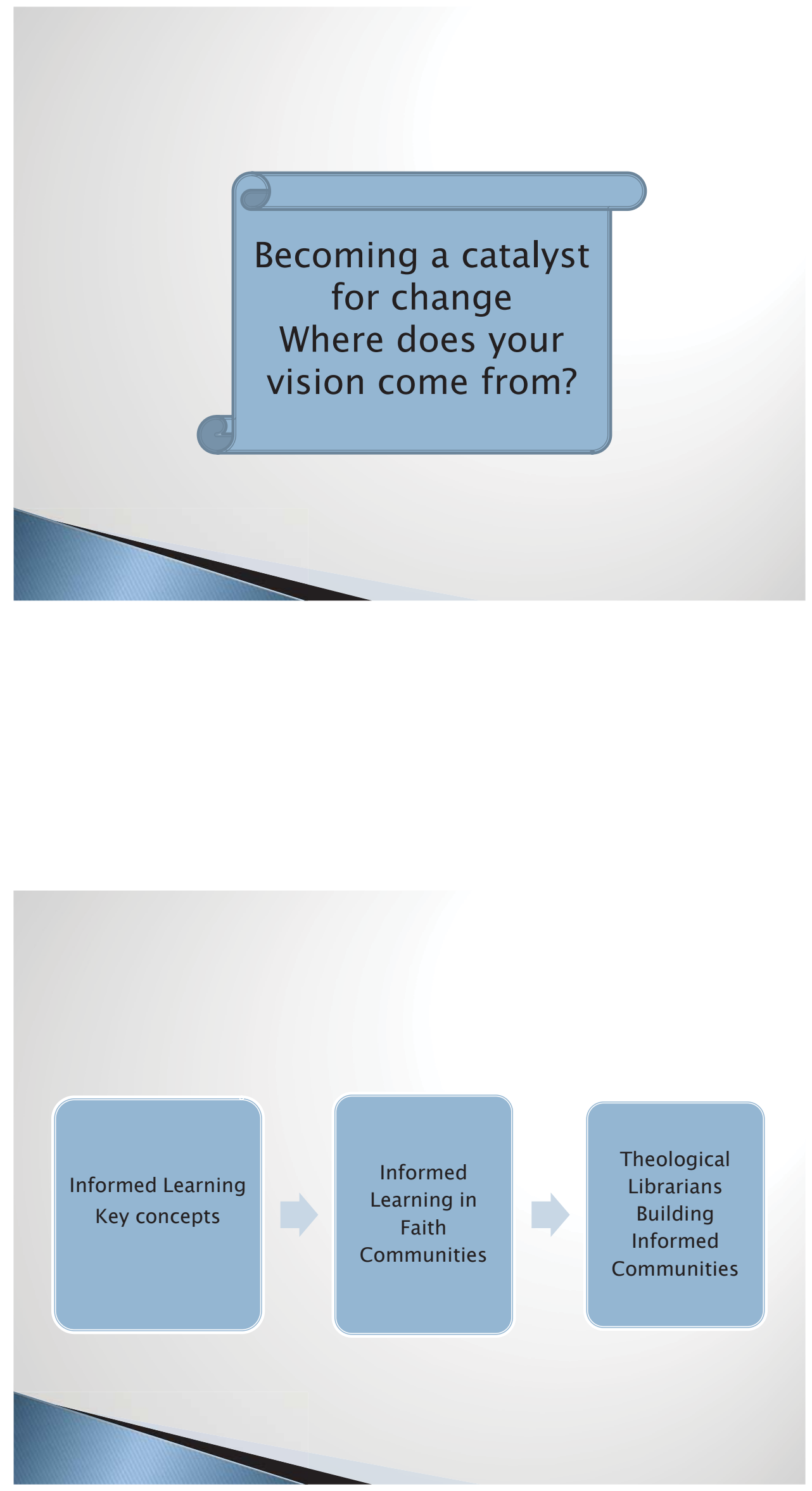


\section{INFORMED LEARNING}

D) On key concepts

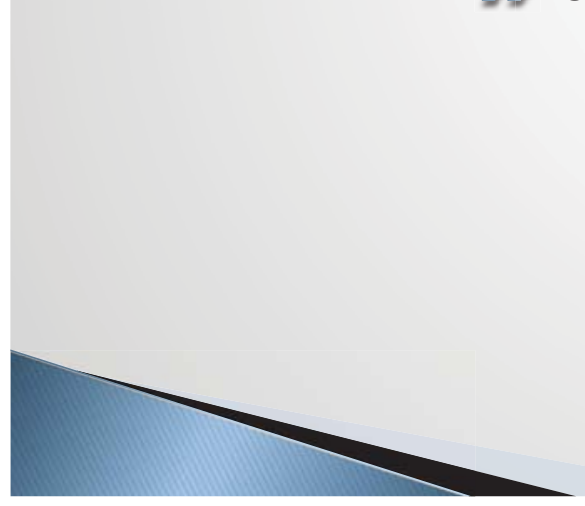

\section{Information experience}

- What does the community we serve experience as information? What informs them as they go about their work, study and spiritual development. How do they use that information?

Dhat does the experience of being an information user look like? What information practices are important? How do people engage with information in these?

- What does it mean to be information literate in the theological/church context.
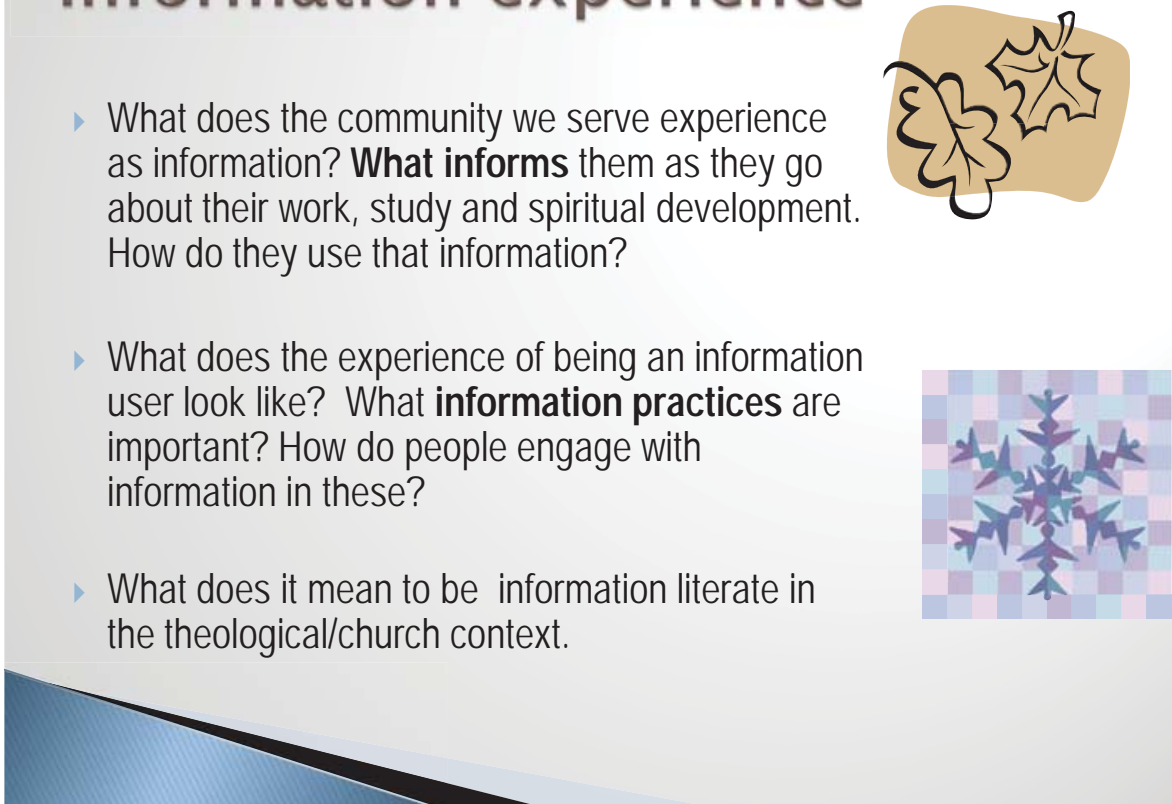


\section{Experiencing Information Use}

- How do people experience information use in the context of the college and beyond its walls?

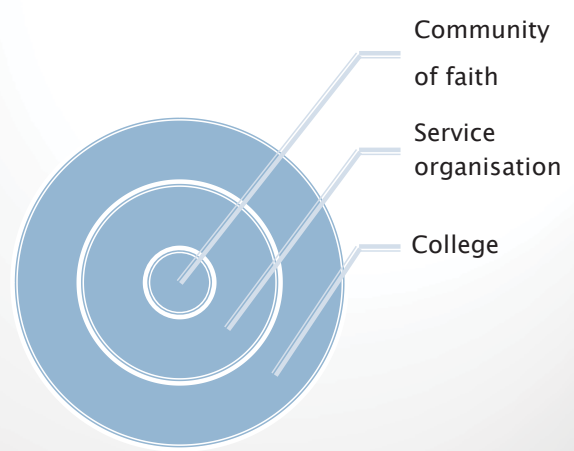

- In the taking up of vocation?

- In the wider community of faith?

\section{Ways of experiencing informaiton}

- Typically, information may be experienced as:

What is experienced as information?

- How do people experience using that information?

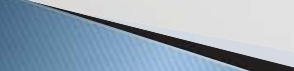




\section{INFORMATION LITERACY: the experience of effective information use}
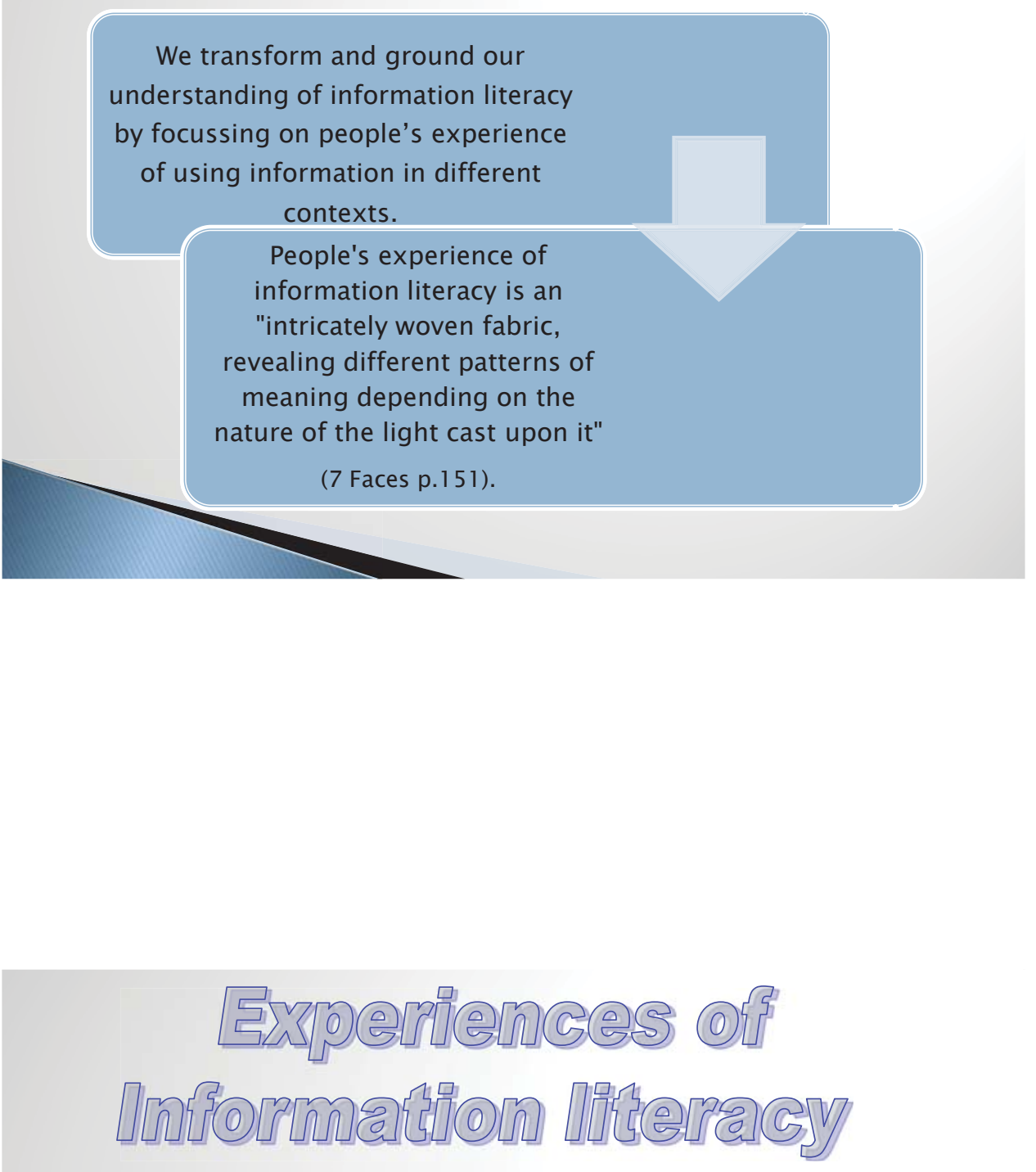

\begin{tabular}{|c|c|}
\hline INSIGHT & WISDOM \\
\hline \multicolumn{2}{|c|}{ KNOWLEDGE BASE } \\
\hline PROCESS & CONTROL \\
\hline \multicolumn{2}{|c|}{ SOURCES } \\
\hline \multicolumn{2}{|c|}{ INFORMATION AWARENESS } \\
\hline
\end{tabular}


From information literacy to informed learning

We can talk about information literacy (experiencing information use in different ways) as being about informed learning (Bruce 2008).

Informed learning is using information creatively, reflectively, effectively and ethically in order to learn in any of life's paths. It is learning that is grounded in the effective information practices of professional, community and academic life.

\section{Why think about information literacy as informed learning?}

.... the word, inform, fits nicely with the roots of the word 'educate'; which comes from the Latin educare which is to lead out or bring out.

Informed Learning brings out the potential within each of us. It fits with the idea that education is our giving shape to ourselves (in-FORM-ing ourselves) by realizing our potential. (David Kent, e-mail correspondence 28-08-09) 


\section{The etymology of 'inform'}

(with thanks to David Kent)

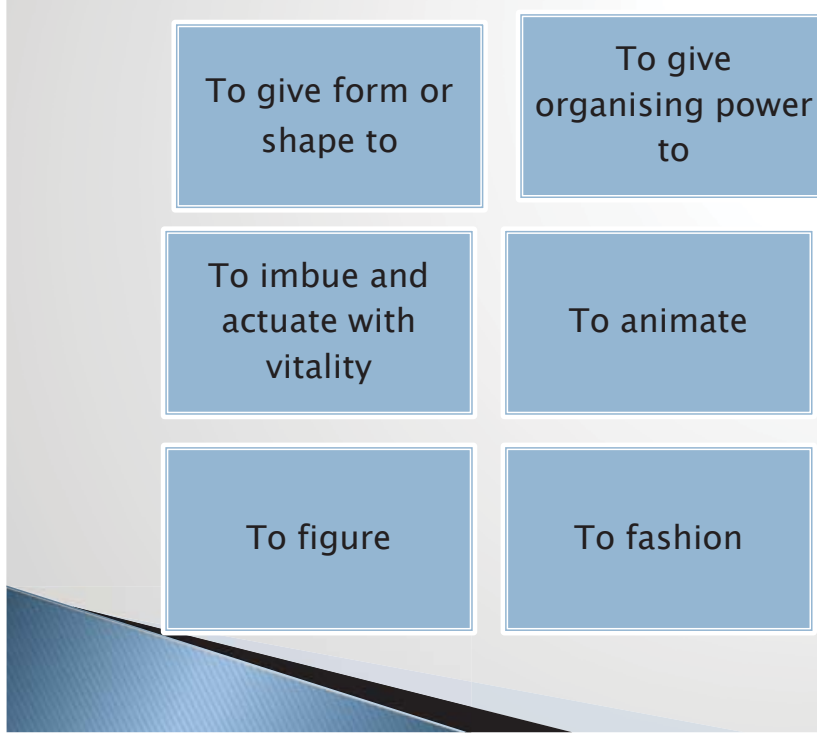

To give life to
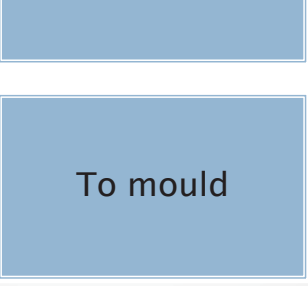

Webster's revised unabridged dictionary (1913)

\section{INFORMED LEARNING}

From having information skills

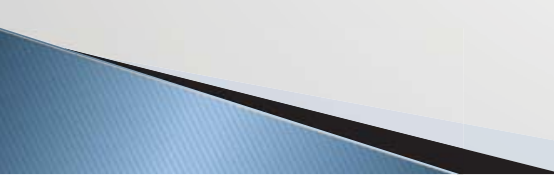

To using information to learn 


\section{INFORMED LEARNING \\ simultaneous attention to what is learned and information use}

Using information
To learn, become aware of something

\section{INFORMED LEARNING}

$\$ 2$ information use in communities of faith, especially the Christian church community and related settings - beyond information literacy for academic purposes? 


\section{Center for the Study of Information and Religion - GOALS http://siris.sis. kent.edu}

To advance

understanding of the role of information in religious practice
To investigate the importance of information in the religious world

To understand the relationship between the information seeking behaviour of clergy and the knowledge that supports them

\section{$1^{\text {st }}$ International Conference on Information and Religion}

Research Frontiers in the Study of Information and Religion

' Keynote: Brenda Dervin 'Spiritual Knowledge'

Papers to become available, also see Annual Review of Information and Religion. May 20, 2011 


\section{Conference topics}

- Information seeking , Information, behaviour of clergy entropy and belief

- Use of multimedia , Longitudinal in sermon delivery studies of the role of information in

- Information and its the development of application to local congregations and communities new congregations or growth of established ones

\section{Journal of College and Character} http://journals.naspa.org/jcc

- Special issue (announced 17/2/2011)

- Role of theological seminaries in increasing interfaith cooperation in the United States

- Youth voices: Why interfaith work must happen on college campuses. 
Informed learning in the church community is experienced as using information in five different ways.

Each of these describes a different experience of using information to learn in the church community:

7. Growing faith

2. Developing relationships

3. Managing the church

4. Serving the community

5. Outreaching beyond the community

Gunton, L Bruce, C. and Stoodley, I. (manuscript), Experiencing religious information literacy.

\section{Using information for growing faith}

Informed learning is experienced as understanding and interpreting communication inspired by God to develop a personal faith journey.

Forms of information (what information): the Bible, artistic expression and narrative, craft, stories, drama and song around the same message.

Approaches to learning (How information is used): personal reflection and study, small group/peer discussion, informal conversation, formal education in the form of workshops, seminars and lectures, and learning by doing. 


\section{Using information for managing the church}

Informed learning is experienced as using collaborative approaches to engage with corporate information to develop administrative functions.

Information: a broad range of documentation, shared in print, digital format via email, or in audio, as presented during meetings or conversations; minutes, quotes, invoices, reports, statistics.

Learning: in groups, where the sharing of information is interactive rather than solitary learning experiences, such as reading or listening.

\section{Using information to serve the community}

Informed learning is experienced as using personal interpretations of gifts and talents in response to needs within the community.

Forms of information: text, such as church notices, and verbal information distributed in face-to-face interactions, such as worship services or committee meetings, including digital information.

Learning by doing, using kinaesthetic styles, putting learning into practice; engaging in acts of service. 


\section{Using information to outreach beyond the community}

Informed learning is experienced as using personal interpretations of gifts and talents in response to needs beyond the church community.

Forms of information: controlled, published, printed formats. Materials provided by charities and other mission organisations. Materials prepared by the church about outreach programs. Commonly received during face-to-face interactions, such as during a worship service.

Learning by doing, using kinaesthetic styles, putting learning into practice; engaging in acts of service.

\begin{tabular}{|c|c|c|c|c|c|}
\hline $\begin{array}{l}\text { Category } \\
\text { Name }\end{array}$ & $\begin{array}{c}\text { IL } \\
\text { experienced } \\
\text { as } \\
\end{array}$ & Focus & $\begin{array}{c}\text { Information } \\
\text { experienced } \\
\text { as } \\
\end{array}$ & $\begin{array}{c}\text { Learning } \\
\text { experienced } \\
\text { as } \\
\end{array}$ & Margin \\
\hline $\begin{array}{l}\text { 1. Growing } \\
\text { faith }\end{array}$ & $\begin{array}{l}\text { Understanding } \\
\text { and } \\
\text { interpreting } \\
\text { communication } \\
\text { inspired by God } \\
\text { to develop a } \\
\text { personal faith } \\
\text { journey } \\
\end{array}$ & $\begin{array}{l}\text { God } \\
\text { Personal } \\
\text { faith } \\
\\
\\
\end{array}$ & $\begin{array}{l}\text { Received } \\
\text { Personalised } \\
\text { with internal } \\
\text { application }\end{array}$ & Reflective & $\begin{array}{l}\text { Relation- } \\
\text { ships }\end{array}$ \\
\hline $\begin{array}{l}2 . \\
\text { Developing } \\
\text { relation- } \\
\text { ships }\end{array}$ & $\begin{array}{l}\text { Using } \\
\text { information } \\
\text { generated } \\
\text { through social } \\
\text { and pastoral } \\
\text { interactions to } \\
\text { grow } \\
\text { celationships }\end{array}$ & $\begin{array}{l}\text { Relation- } \\
\text { ships with } \\
\text { people }\end{array}$ & $\begin{array}{l}\text { Relational } \\
\text { Shared with } \\
\text { others }\end{array}$ & Communal & $\begin{array}{l}\text { Management } \\
\text { issues }\end{array}$ \\
\hline
\end{tabular}




\begin{tabular}{|l|l|l|l|l|l|}
\hline $\begin{array}{c}\text { Category } \\
\text { Name }\end{array}$ & $\begin{array}{l}\text { IL experienced } \\
\text { as }\end{array}$ & \multicolumn{1}{|c|}{ Focus } & $\begin{array}{c}\text { Information } \\
\text { experienced } \\
\text { as }\end{array}$ & $\begin{array}{c}\text { Learning } \\
\text { experienced } \\
\text { as }\end{array}$ & \multicolumn{1}{|c|}{ Margin } \\
\hline $\begin{array}{l}\text { M. } \\
\text { Managing } \\
\text { the church }\end{array}$ & $\begin{array}{l}\text { Using } \\
\text { collaborative } \\
\text { approaches to } \\
\text { engage with } \\
\text { corporate } \\
\text { information to } \\
\text { develop } \\
\text { administrative } \\
\text { functions }\end{array}$ & $\begin{array}{l}\text { or } \\
\text { operations } \\
\text { of the } \\
\text { church }\end{array}$ & Systematic & $\begin{array}{l}\text { Evidence } \\
\text { based }\end{array}$ & $\begin{array}{l}\text { Own service } \\
\text { role in the } \\
\text { community }\end{array}$ \\
\hline
\end{tabular}

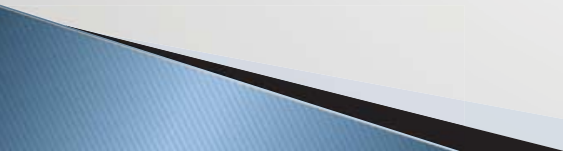

\begin{tabular}{|c|c|c|c|c|c|}
\hline $\begin{array}{l}\text { Category } \\
\text { Name }\end{array}$ & $\begin{array}{c}\text { IL } \\
\text { experienced } \\
\text { as }\end{array}$ & Focus & $\begin{array}{c}\text { Information } \\
\text { experienced } \\
\text { as }\end{array}$ & $\begin{array}{c}\text { Learning } \\
\text { experienced } \\
\text { as }\end{array}$ & Margin \\
\hline $\begin{array}{l}\text { 4. Serving } \\
\text { the } \\
\text { community }\end{array}$ & $\begin{array}{l}\text { Personal } \\
\text { interpretation } \\
\text { of gifts and } \\
\text { talents in } \\
\text { response to } \\
\text { needs within } \\
\text { the } \\
\text { community } \\
\end{array}$ & $\begin{array}{l}\text { Service } \\
\text { within the } \\
\text { community }\end{array}$ & $\begin{array}{l}\text { Personalised } \\
\text { with external } \\
\text { application } \\
\text { Responsive }\end{array}$ & Kinaesthetic & $\begin{array}{l}\text { Issues } \\
\text { outside the } \\
\text { community }\end{array}$ \\
\hline $\begin{array}{l}5 . \\
\text { Outreaching } \\
\text { beyond the } \\
\text { community }\end{array}$ & $\begin{array}{l}\text { Personal } \\
\text { interpretation } \\
\text { of gifts and } \\
\text { talents in } \\
\text { response to } \\
\text { needs beyond } \\
\text { the church } \\
\text { mmunity. }\end{array}$ & $\begin{array}{l}\text { Service } \\
\text { outside the } \\
\text { community }\end{array}$ & $\begin{array}{l}\text { Personalised } \\
\text { with } \\
\text { application } \\
\text { beyond the } \\
\text { community } \\
\text { Responsive }\end{array}$ & $\begin{array}{l}\text { Kinaesthetic } \\
\text { Responsive }\end{array}$ & $\begin{array}{l}\text { Proactivity } \\
\text { Other faiths }\end{array}$ \\
\hline
\end{tabular}




\section{INFORMED LEARNING}

28) Theological librarians building informed communities

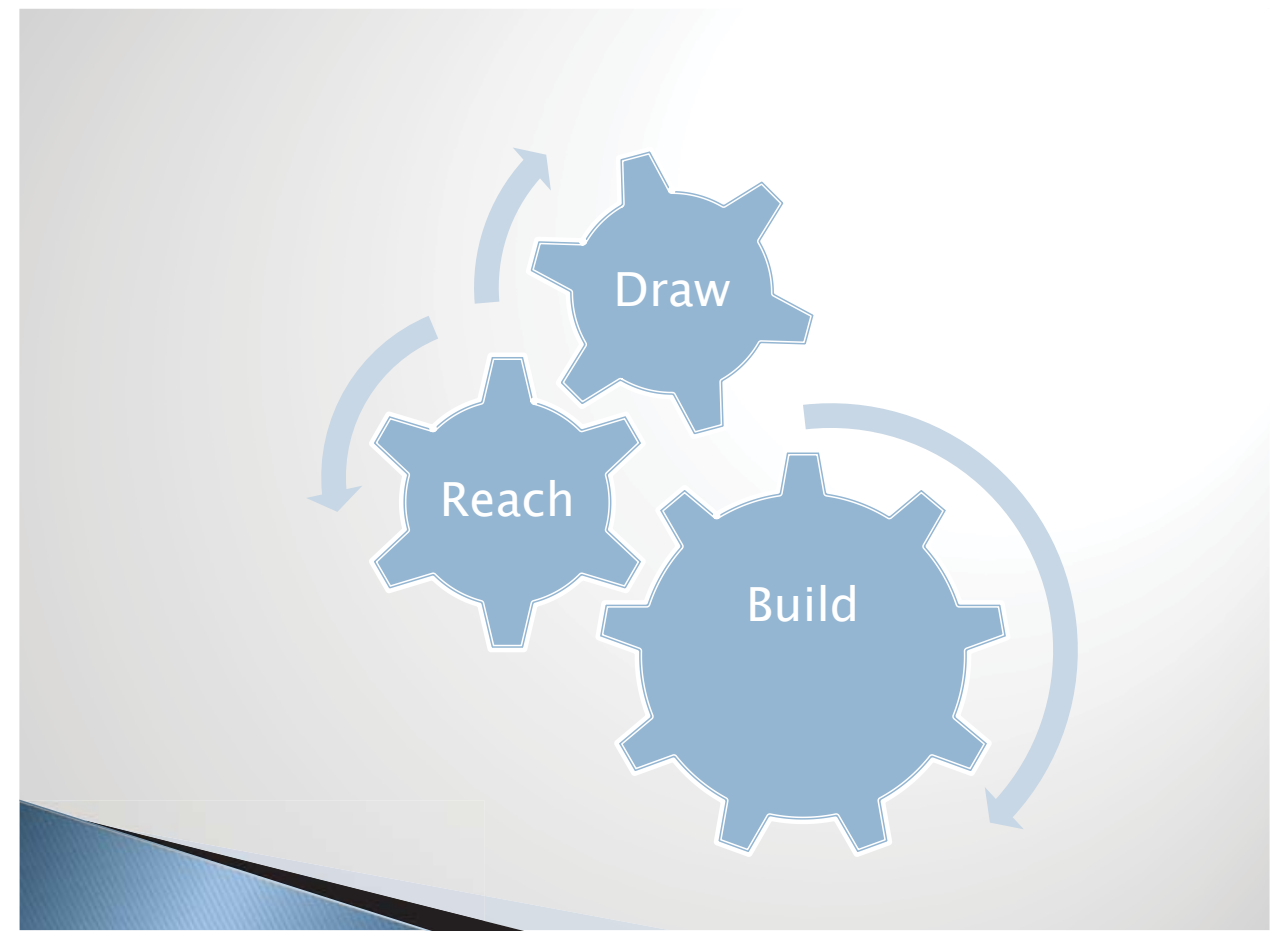



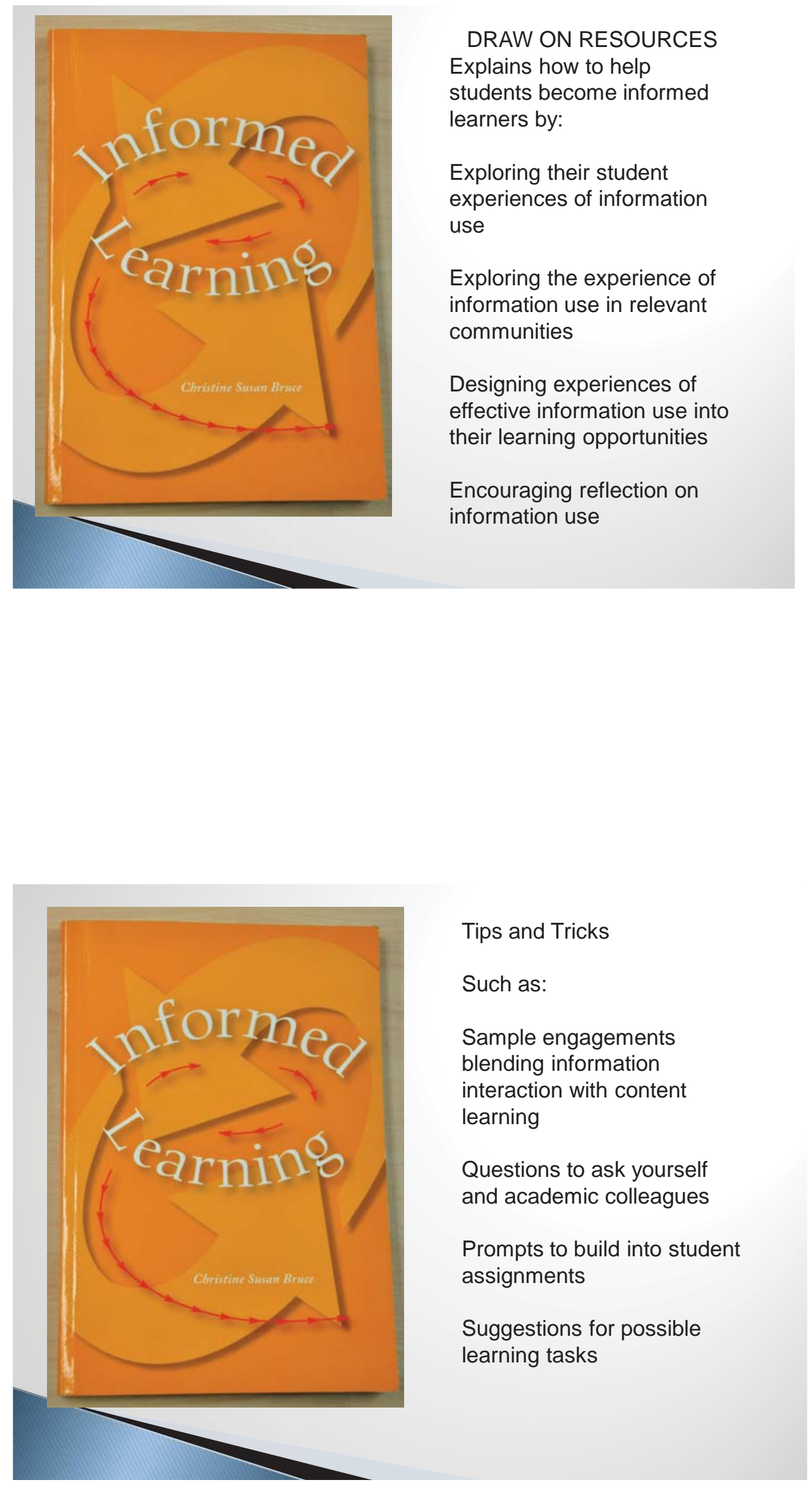


\section{DRAW attention to experiences of information use}

From a range of communities.

To widen the horizons of students and other members of the college community.

Use the wide research base in information literacy and information use in academic and community contexts.

\section{DRAW attention to experiences of using information to learn}

- In the wider academic community

In faith communities

In other relevant context

- Help people become more aware of 'how information can be actively used to grow faith, develop relationships, manage the church ... thereby supporting the pursuit of spiritual wellness and the cultivation of lifelong learning.

Lyndelle Gunton, (2011), Religious information literacy; using information to learn in church community. 


\section{REACH forward from skills}

Consider the information experience of members of the community, as well as those beyond the community; including the experience of less represented/ marginalised groups
- Take an interest in the broader needs of the learning community and how it might be possible to serve them

Think and talk about what the library could do to help

\section{REACH beyond skills: Librarians'}

experiences of Information literacy

\section{Practical}

Information literacy is experienced through the purposeful acquisition of technical skills
Social

Information literacy is experienced organically through the process of socialisation (being part of a learning community)

Demasson, Andrew E., et al (2010) How do public librarians constitute information literacy? In 5 th Int. Conf. on Qualitative Research in IT \& IT in Qualitative Research (QuallT2010), 29-30 Nov. 2010, QUT., Brisbane, QLD

http://eprints.qut.edu.au/39896/1/c39896.pdf 


\section{REACH BEYOND SKILLS}

Information literacy (education is not) teaching a set of skills but rather a process that should transform both learning and the culture of communities for the better.

(Breivik, P. (2000) Foreword, Information Literacy Around the World, edited by C Bruce and $\mathrm{P}$, Candy
We can help people learn by understanding the learners' perspective, and

Help people become better information users by understanding their information experiences. 


\title{
Partner and Collaborate
}

\author{
With...
}

College staff, other colleges

Members of the church community

Other libraries, BCC, SLQ, academic

- Researchers and research projects

- Funders/decision makers - lobby!

\section{Partnering in learning design}

Identify a small

number of learning

strategies that

encourage information

use and awareness.

- Talk about them and encourage academics to ask their students to reflect on their information use
- When researching for essays students could write about the different forms of information they have used and critique value to their learning.

Embed info practices, eg creating current awareness strategies and reflecting on what is learned on implementation. 


\section{Partnering in academic development}

Bring students information needs and experiences to the attention of their teachers

Bring the information experiences of the faith community to peoples attention.
- Share articles, papers, books

- Identify a key message that you want to be your own and repeat it, everywhere...!

\section{Partnering in ensuring the spiritual wellness of the college community}

- We have seen how people use information in different ways in their faith walk (Gunton, 2011).

Librarians can bring this kind of knowledge to the table and partner or indeed lead the process of building spiritual wellness in the college community and beyond. 


\section{Cultivating the Spirit}

Findings show that religious engagement declines during college, but spirituality shows substantial growth.

Students become more caring, more tolerant, more connected with others, and more actively engaged in a spiritual quest. The study identified a number of college activities that contribute to students' spiritual growth.

Spiritual growth enhances academic performance, psychological well-being, leadership development, and satisfaction with college.

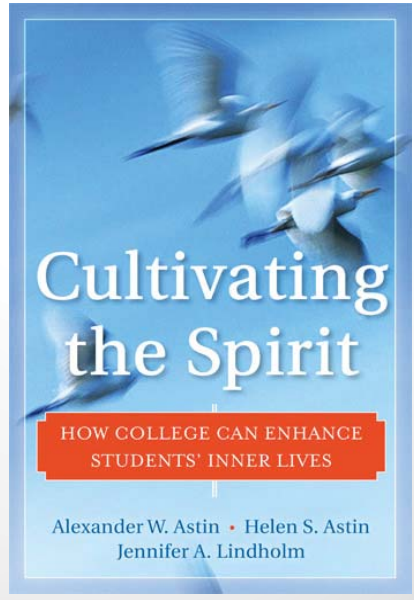

\section{Building library services}

Should we redesign library services according to peoples information experiences ( their interesting, complex ways of using information) instead of fitting them to our services?
How can we take peoples real life information experiences more seriously? Designing services and learning to suit them rather than expecting them to fit traditional moulds? 


\section{Theological libraries}

Theological libraries have the potential to contribute to the academic library agenda around the issue of attending to spiritual growth and personal transformation in the learning community.

\section{What can I do}

Something small

Something focussed

- Something targeted at a key group that will benefit

- Something that will involve those responsible for funding and the well being of the college/library 


\section{Acknowledgements}

ANZTLA for inviting the contribution

The QUT information studies research team for the intense intellectual effort in this area

Lyndelle Gunton and Dr lan Stoodley for their particular interest in informed learning in faith communities

Information Systems Discipline for providing a summer scholarship to assist Lyndelle to continue the work

- Uniting Church of Australia for hosting Lyndelle's research 